\title{
26. GEOCHEMISTRY OF BURIED MIOCENE-PLEISTOCENE FERROMANGANESE NODULES FROM THE ANTARCTIC OCEAN
}

\author{
F. Aumento and J. M. MacGillivray, Department of Geology, Dalhousie University, Halifax, \\ Nova Scotia, Canada
}

\begin{abstract}
Five nodules collected on Leg 28 of the Deep Sea Drilling Project are unique in that they provide an opportunity of studying older, buried nodules. Paleontological evidence from the cores suggests they may be from Miocene to Pliocene in age. The thinness of the ferromanganese coatings on the nuclei suggests that rapid burial took place. They differ from the few analyzed surface nodules from the South Pacific in that the Mn and Ni concentrations of the buried nodules are lower, and the Co concentrations are slightly higher. The $\mathrm{Fe}$ and $\mathrm{Cu}$ concentrations are similar. There is no evidence that either leaching or remobilization of any of these elements has taken place subsequent to burial.
\end{abstract}

\section{INTRODUCTION}

Five ferromanganese nodules were found in the cores collected on Leg 28 of the Deep Sea Drilling Project (Table 1). The nodules are all buried, four of them from different horizons of the same hole. The locations of the cores and the nodules within them are shown in Figure 1. Four surface nodule occurrences are also shown and are included for subsequent comparison purposes. Table 2 describes the physical characteristics of the nodules under investigation.

An electron microprobe was used to determine the relative distributions of the major elements within the nodules, to compare their distribution with that known of Recent nodules, and to detect geochemical changes these nodules may have undergone during burial.

\section{EXPERIMENTAL TECHNIQUES}

The nodules were cut to expose their concentric layering and then mounted in epoxy. The flat surfaces so exposed were impregnated with hot, diluted epoxy under vacuum, and when this had set, they were polished. Due to the porosity and friability of the specimens the

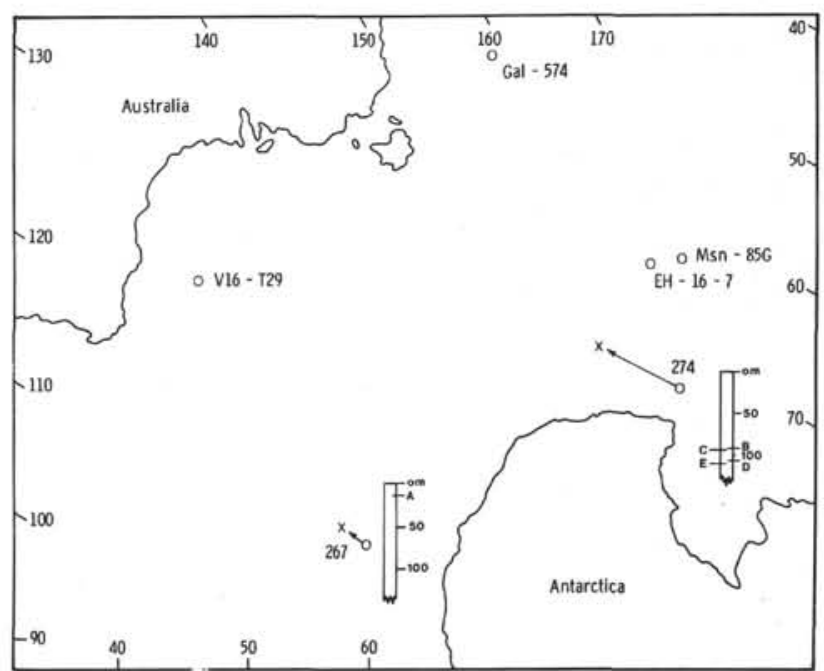

Figure 1. Locations of coring Sites 267 and 274 and sample locations for four Pacific nodules. Crosses indicate probable position of nodules on surface at time of formation.

TABLE 1

Locations of Nodules from Leg 28, DSDP

\begin{tabular}{|c|c|c|c|c|c|c|}
\hline Nodule & Hole & Position & $\begin{array}{l}\text { Water } \\
\text { Depth } \\
\text { (m) }\end{array}$ & Core & $\begin{array}{c}\text { Depth of } \\
\text { Nodule Below } \\
\text { Sea Floor (m) }\end{array}$ & Age \\
\hline A & 267 & $\begin{array}{l}59^{\circ} 15.74^{\prime} \mathrm{S} \\
104^{\circ} 29.30^{\prime} \mathrm{E}\end{array}$ & 4522 & $1 \mathrm{~A}$ & 12 & Pleistocene \\
\hline B & 274 & $\begin{array}{l}68^{\circ} 59.81^{\prime} \mathrm{S} \\
173^{\circ} 25.64^{\prime} \mathrm{E}\end{array}$ & 3305 & 10 & 93 & Miocene \\
\hline $\mathrm{C}$ & 274 & $\begin{array}{l}68^{\circ} 59.81^{\prime} \mathrm{S} \\
173^{\circ} 25.64^{\prime} \mathrm{E}\end{array}$ & 3305 & 10 & 93.5 & Miocene \\
\hline D & 274 & $\begin{array}{l}68^{\circ} 59.81^{\prime} \mathrm{S} \\
173^{\circ} 25.64^{\prime} \mathrm{E}\end{array}$ & 3305 & 12 & 105.5 & Miocene \\
\hline E & 274 & $\begin{array}{l}68^{\circ} 59.81^{\prime} \mathrm{S} \\
173^{\circ} 25.64^{\prime} \mathrm{E}\end{array}$ & 3305 & 12 & 108 & Miocene \\
\hline
\end{tabular}


TABLE 2

Physical Characteristics of Nodules from Leg 28, DSDP

\begin{tabular}{|c|c|c|c|c|}
\hline Nodule & Nucleus & $\begin{array}{l}\text { Color and } \\
\text { Consistency }\end{array}$ & Size $(\mathrm{cm})$ & $\begin{array}{c}\text { Thickness of } \\
\text { Encrustation (mm) }\end{array}$ \\
\hline A & $\begin{array}{l}\text { Coarse-grained } \\
\text { quartzite }\end{array}$ & $\begin{array}{l}\text { Dark brown, } \\
\text { friable }\end{array}$ & $1 \times 0.5 \times 0.25$ & $\begin{array}{ll}\max & 0.738 \\
\min & 0.062 \\
\text { av } & 0.400\end{array}$ \\
\hline B & $\begin{array}{c}\text { Fine-grained } \\
\text { quartzite }\end{array}$ & $\begin{array}{l}\text { Dark brown, } \\
\text { friable }\end{array}$ & $1 \times 1.5 \times 1$ & $\begin{array}{ll}\max & 0.615 \\
\min & 0.062 \\
\text { av } & 0.339\end{array}$ \\
\hline C & $\begin{array}{l}\text { Pinkish, soft } \\
\text { clay }\end{array}$ & $\begin{array}{l}\text { Dark brown, } \\
\text { friable }\end{array}$ & $1 \times 1 \times 0.5$ & $\begin{array}{ll}\max & 2.7 \\
\min & 0.5 \\
\text { av } & 1.6\end{array}$ \\
\hline D & $\begin{array}{l}\text { Fine-grained } \\
\text { quartzite }\end{array}$ & $\begin{array}{l}\text { Dark brown, } \\
\text { friable }\end{array}$ & $4 \times 3.5 \times 2.5$ & 0.05 \\
\hline E & No nucleus & $\begin{array}{c}\text { Yellow-brown, } \\
\text { hard packed }\end{array}$ & $0.5 \times 0.5 \times 0.1$ & \\
\hline
\end{tabular}

impregnation-polishing procedure had to be repeated a number of times before a surface good enough for electron probe analysis was obtained.

High-resolution mosaic photographs of the entire nodule sections were then made with reflected light microscopy at a magnification of $75 \times$. The mosaics were used to select traverses across which continuous electron probe analyses were to be made (Figures 2-10). The traverses were selected to provide a section through the most continuous and well-defined series of laminations for each nodule.

Two scans on nodules A, B, and C, and one on D and $E$ were made with a Cambridge Geoscan MK5 electron microprobe. An electron beam width of $1 \mu$ and a scanning speed of $30 \mu / \mathrm{min}$ were used in each case. Nine elements were determined along the chosen traverses: $\mathrm{Fe}, \mathrm{Mn}, \mathrm{Co}, \mathrm{Ni}, \mathrm{Cu}, \mathrm{Ti}, \mathrm{Ca}, \mathrm{Si}$, and $\mathrm{Al}$. Since the probe had only two spectrometers, one spectrometer was set for $\mathrm{Fe}$ and used as the standard against which the locations of the other element concentrations were determined. An extra scan, for K, was made on nodule E.

Five spot analyses-three on nodule $\mathrm{C}$ and two on nodule A-were carried out after the scans were completed. The spots were chosen in areas where the scans had shown the existence of high metallic content. These results are given in Table 3.

Standards against which the different quantitative elemental concentrations were determined included magnetite for $\mathrm{Fe}, \mathrm{Mn} / \mathrm{Co}$ metal for $\mathrm{Mn}$ and $\mathrm{Co}$; $\mathrm{Cu}_{1.0} \mathrm{~S}$ for $\mathrm{Cu} ; \mathrm{Ni}_{1.07} \mathrm{~S}_{1.0}$ for $\mathrm{Ni}$; $\mathrm{AGS}_{14}$ for $\mathrm{Ti}$ and $\mathrm{Ca}$; $\mathrm{Gnt}$ 12442 for $\mathrm{Si}$ and $\mathrm{Al}$; hornfels sanidine for $\mathrm{Na}$ and $\mathrm{K}$; and biotite $\mathrm{LP}_{6}$ for $\mathrm{Zn}$.

$\mathrm{H}_{2} \mathrm{O}$ was determined on bulk samples by the Penfield method.

\section{RESULTS}

Integrated average elemental compositions along the traverses for all the nodules are presented in Table 4. Nodules $\mathrm{D}$ and $\mathrm{E}$ proved to be so low in both $\mathrm{Fe}$ and $\mathrm{Mn}$ and so high in $\mathrm{Ca}, \mathrm{Si}$, and $\mathrm{Al}$, that they could not justifiably be called manganese nodules.

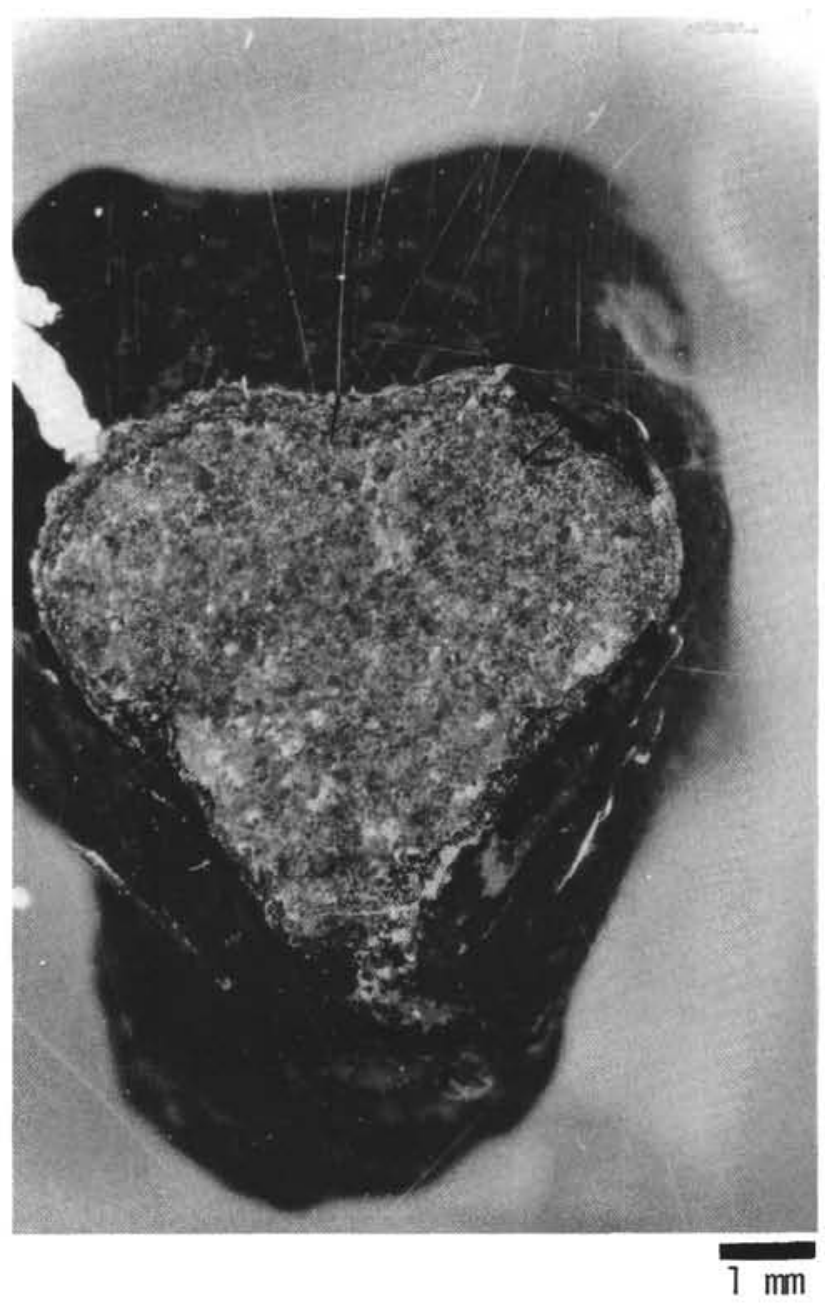

Figure 2. Scan areas, nodule A. Black lines indicate locations of scans.

As expected, high metal contents were usually found in the bright areas seen in reflected light. Very dark areas usually turned out to be epoxy-impregnated holes. 


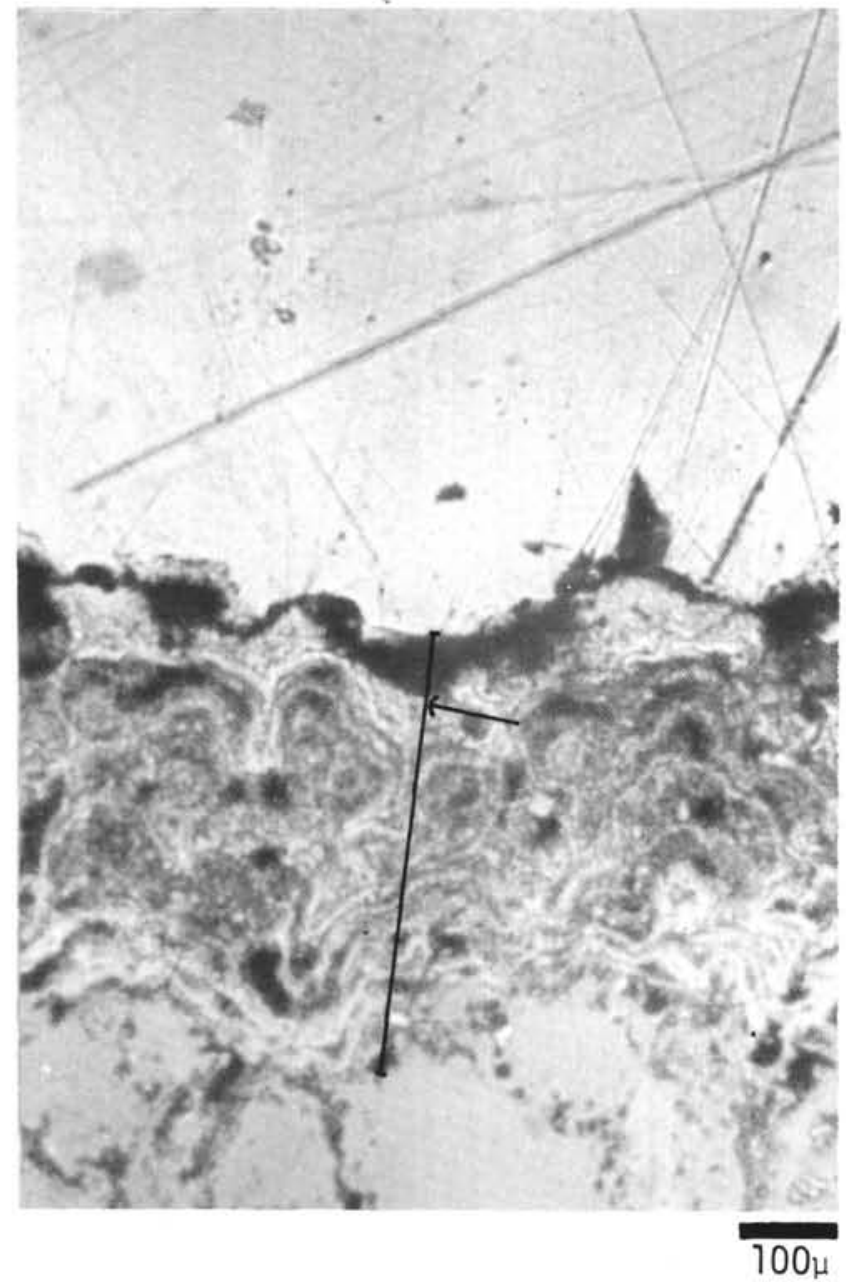

Figure 3. Nodule A, scan 1. Arrows indicate location of spot analyses reported in Table 3.

Scans show that $\mathrm{Fe}$ and $\mathrm{Mn}$ concentrations are generally antipodal. Some scans, for example, 1 and 2 of nodule C, show this very well. On others, it is difficult to see as, due to the porous nature of the surfaces, there were many holes, causing rapid drops in both elemental concentrations followed by correspondingly marked rises.

Co parallels $\mathrm{Mn}$ and is antipodal to $\mathrm{Fe}$. This is in direct contrast to the findings of Burns and Fuerstenau (1966), who found that there was a distinct positive correlation between $\mathrm{Fe}$ and $\mathrm{Co}$ in the nodules they examined from the surface of the Pacific Ocean bottom. It is in agreement, however, with the results obtained by Aumento et al. (1968) from the manganese pavement on San Pablo seamount. The parallel nature of Co to $\mathrm{Mn}$ was evident in all scans.

Both $\mathrm{Cu}$ and $\mathrm{Ni}$ parallel $\mathrm{Co}$ and $\mathrm{Mn}$, which is in agreement with the findings of Burns and Fuerstenau (1966). In one area (nodule B, scan 1), what was thought to be a hole contained a high $(2.0 \%) \mathrm{Cu}$ concentration.

An interesting area occurs in nodule $\mathrm{C}$, scan 2. An area low both in $\mathrm{Fe}$ and $\mathrm{Mn}$, shows $\mathrm{Co}, \mathrm{Cu}$, and $\mathrm{Ni}$ peaks of $1.5 \%, 2.5 \%$, and $2 \%$, respectively. This is inter-

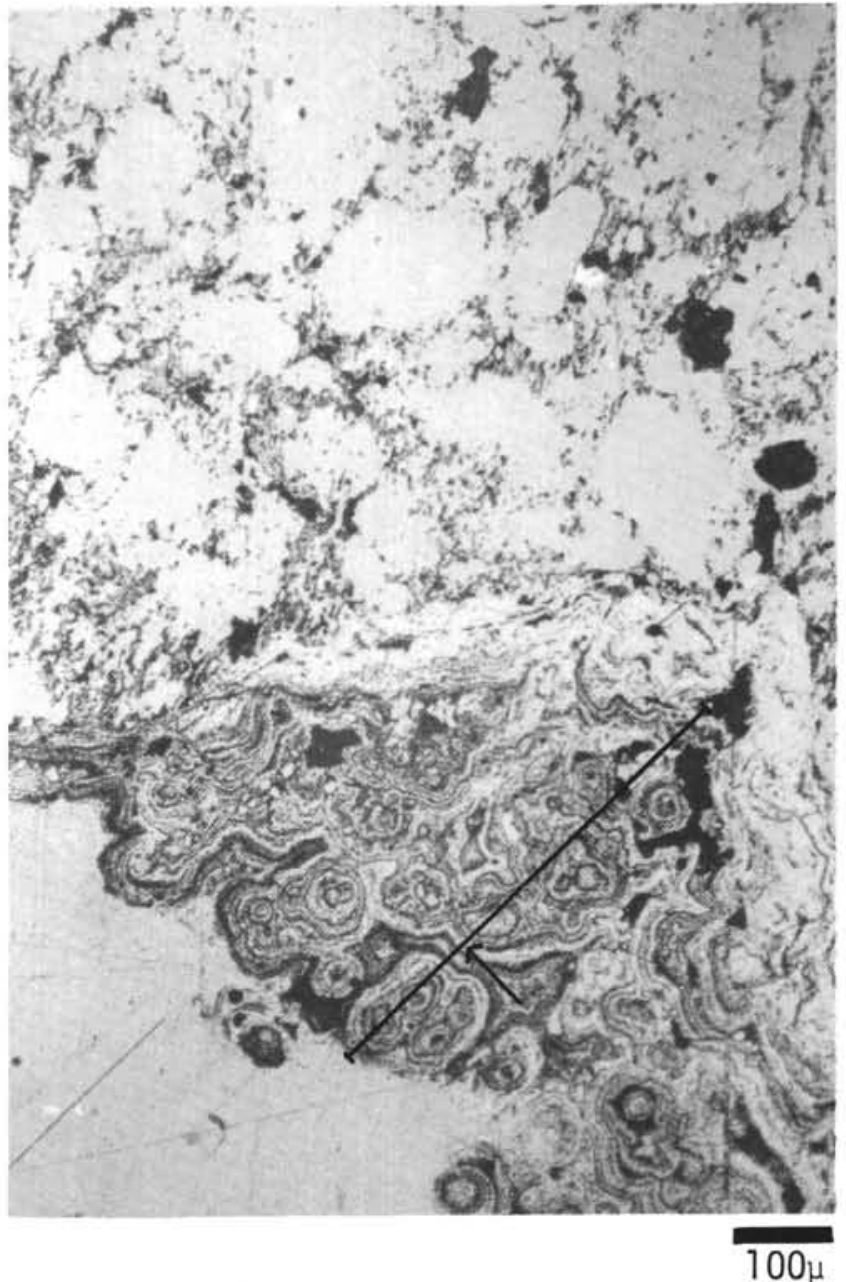

Figure 4. Nodule A, scan 2.

preted as being a foreign grain enriched in these elements.

The $\mathrm{Ti}$ scans parallel $\mathrm{Fe}$ more closely than any other element. This is very evident in nodule C, scan 2 .

Results for the five spot analyses carried out are given in Table 3. The spots were chosen from areas on the scans which had high $\mathrm{Fe}$ and/or Mn concentrations. A discrepancy of $1 \mu$ may exist for the locations of the spots on the scans. The spots all appear as bright areas in reflected light (Figures 3,4, and 9) and are probably well crystallized $\mathrm{Fe} / \mathrm{Mn}$ minerals. Table 3 shows that Co correlates positively with $\mathrm{Mn}$, but no other element shows any such pattern. The total absence of $\mathrm{Ni}$ in all the three spot locations in nodule $\mathrm{C}$ is interesting, especially when Figure 11 indicates that $\mathrm{Ni}$ does parallel $\mathrm{Mn}$.

$\mathrm{High} \mathrm{Ca}, \mathrm{Si}$, and $\mathrm{Al}$ areas are considered to be silicate grain impurities. Scans over these areas do not resemble any of the others, often showing peaks in areas of low metal content. It was noted, however, that $\mathrm{Ca}$ and $\mathrm{Si}$ are antipodal.

\section{DISCUSSION}

No preferred metal concentrations were detected at either the cores or the outer surfaces of these nodules, 


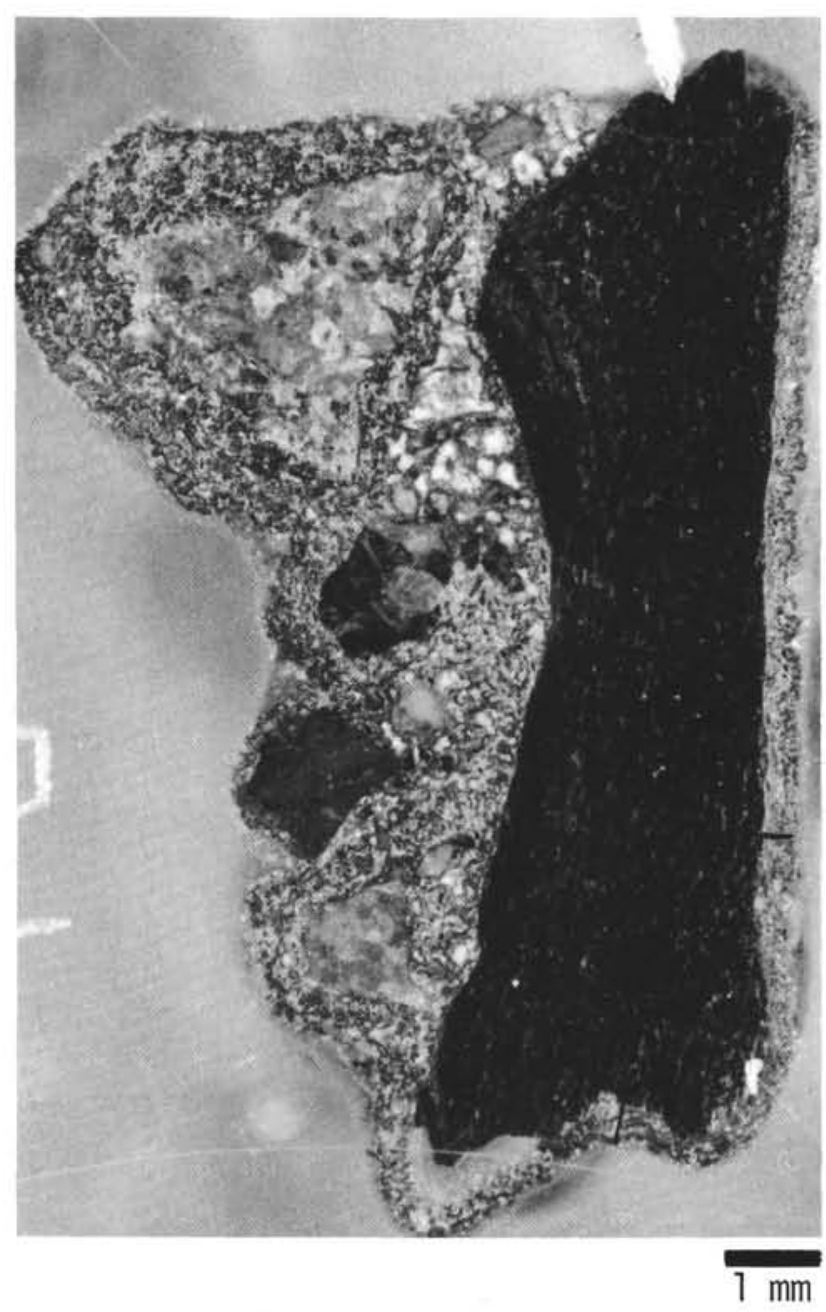

Figure 5. Scan areas, nodule B. Black lines indicate locations of scans.

nor were there any concentration gradients parallel to any radial direction, as might have been expected from leaching or remobilization of the metals during burial. This is evident in Figure 11, and especially Figure 12, where a migration of say $\mathrm{Mn}$ relative to $\mathrm{Fe}$ would have disturbed the clear negative correlation between the two elements.

Cronan and Tooms (1969) showed that the Pacific Ocean could be divided into various zones based on the $\mathrm{Mn} / \mathrm{Fe}$ ratios. In keeping with their description of surface nodules from the south and west Pacific Ocean, these buried nodules have $\mathrm{Mn} / \mathrm{Fe}$ ratios of less than one.

The buried nodules have very low $\mathrm{Mn} / \mathrm{Co}(<21)$ ratios which, according to Arrhenius et al. (1964), indicates rapid metal deposition; similarly, the relatively thin ferromanganese coating on the different nuclei suggests that pelagic sedimentation was also rapid enough to cover these nodules before metal depositions could continue to any great extent.

Fe values, ranging from $8.10 \%$ to $15.15 \%$, compare favorably with values from the four surface nodules given for comparison and also with Cronan's average

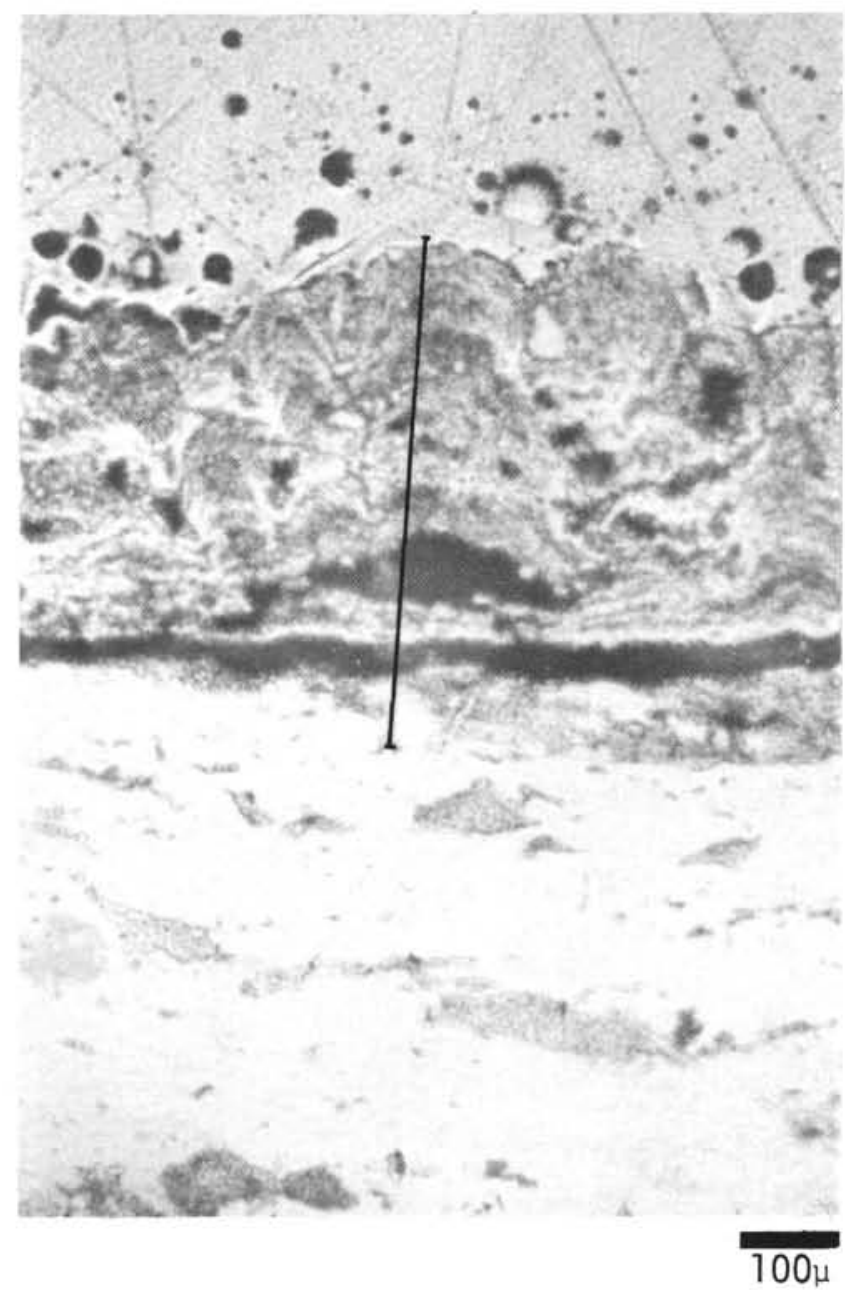

Figure 6. Nodule B, scan 1 .

value for the South Pacific (13.92\%). Mn and Ni values are distinctly lower than those of any of the surface samples cited. The average $\mathrm{Mn}$ value reported here is about $7 \%$, compared to Cronan's $16 \%$; the average $\mathrm{Ni}$ value for the buried nodules is about $0.26 \%$; Cronan's value is $0.43 \% . \mathrm{Cu}$ content is slightly higher than Cronan's figure of 0.185 , but about the same as the average content of the four surface samples $(0.35 \%)$. The average Co value is slightly lower than that of the South Pacific average $(0.48 \%$ and $0.59 \%$, respectively), and slightly higher than the average $0.39 \%$ of the four surface nodules.

\section{CONCLUSIONS}

The results indicate that except for the lower Mn content, the buried nodules are very similar to recent surface nodules. Because of the scarcity of samples from this area and because of the distances involved between surface samples used for comparison purposes, it is difficult to ascertain whether any depositional environment changes have taken place from Miocene times to the present.

It is possible to suggest, however, that there are indications from the $\mathrm{Mn} / \mathrm{Co}$ ratio that the 


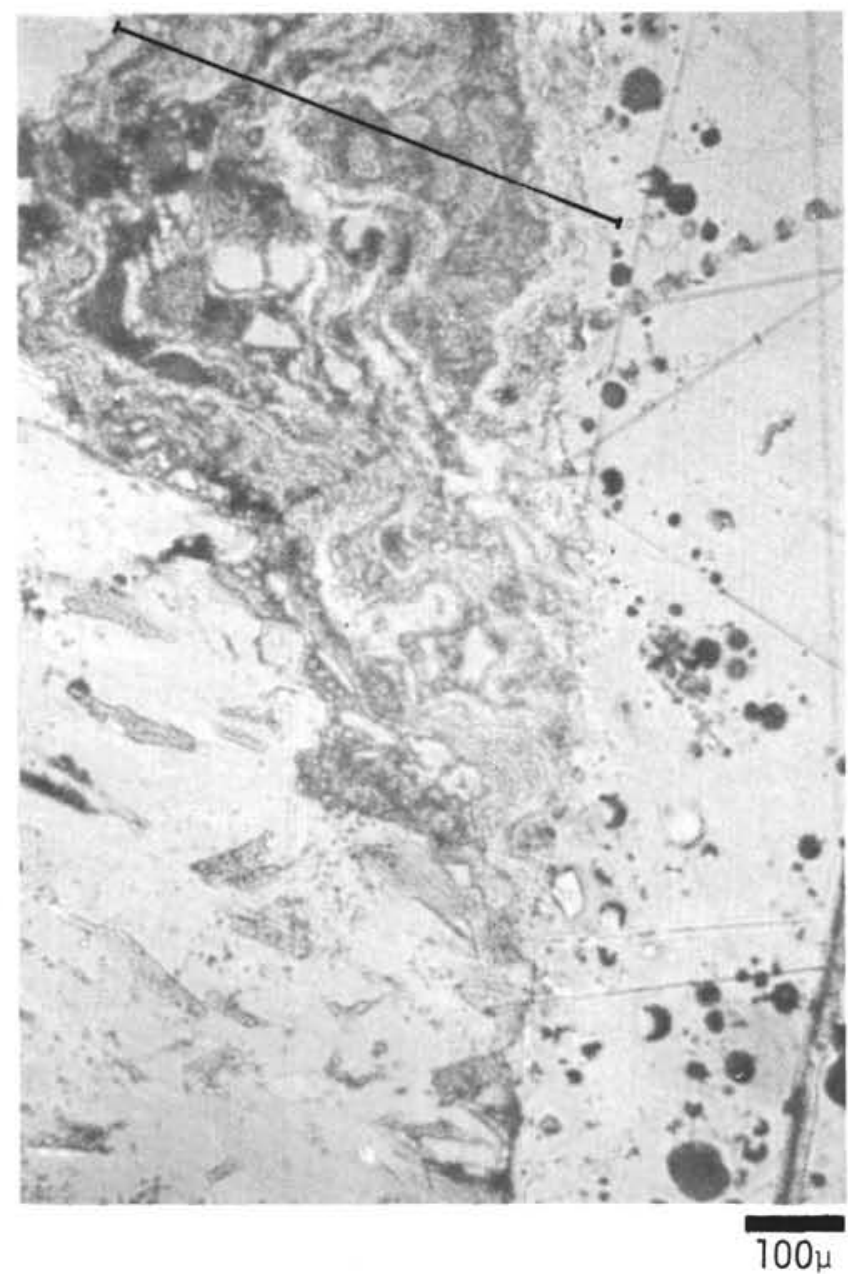

Figure 7. Nodule B, scan 2.

ferromanganese concentrations grew quite rapidly and that they were buried soon after their formation, thereby halting any subsequent growth. The lower Mn content of these nodules may be due to leaching, but since there remains no evidence of any migration of this or any other metal, it is more probable that it represents an original depositional characteristic.

\section{REFERENCES}

Arrhenius, G., Mero, J., and Korkisch, J., 1964. Origin of oceanic manganese minerals: Science, v. 144, p. 170-173.

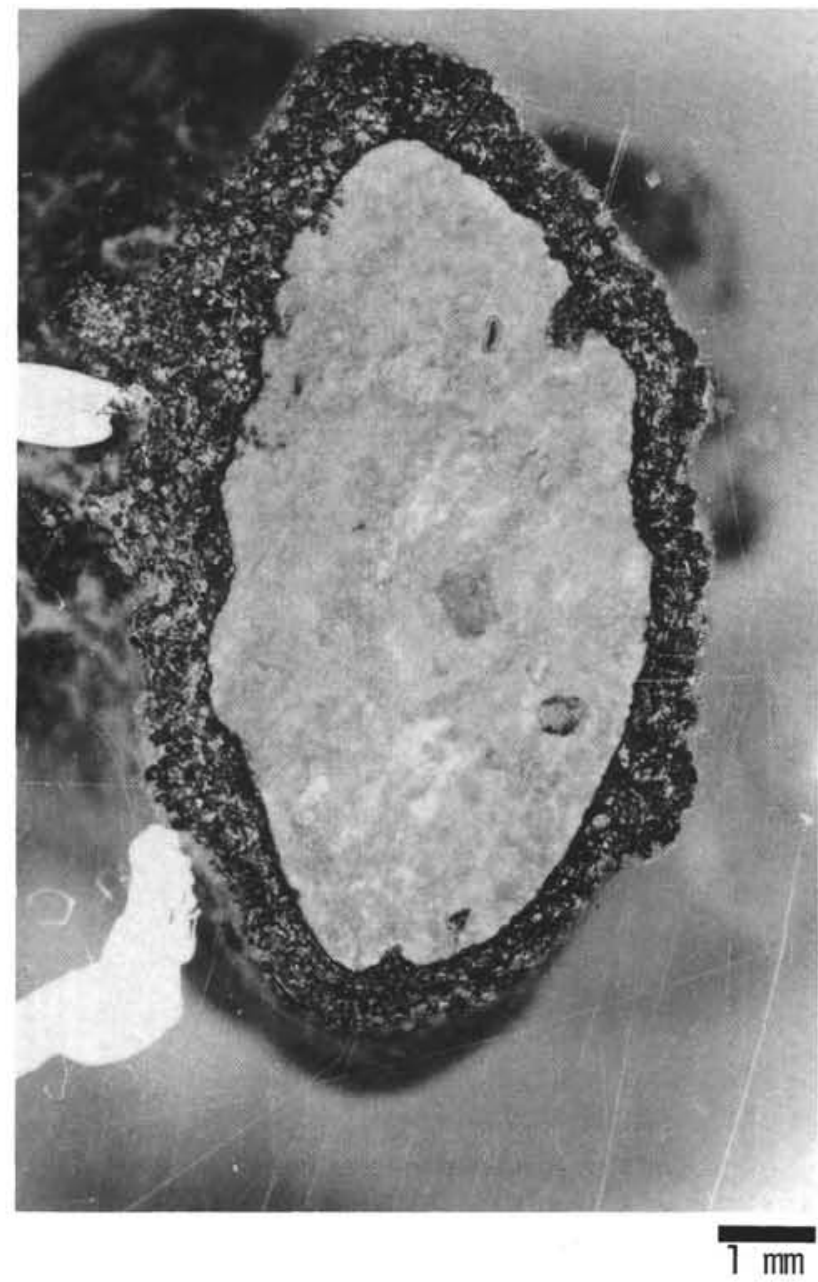

Figure 8. Scan areas, nodule $C$. Black lines indicate locations of scans.

Aumento, F., Lawrence, D. E., and Plant, A. G., 1968. The Ferro-Manganese pavement on San Pablo Seamount: Geol. Surv. Canada, Paper 68-32.

Burns, R. G. and Fuerstenau, D. W., 1966. Electron probe determination of interelement relationships in manganese nodules: Am. Min.,v. 51, p. 895-902.

Cronan, D. S. and Tooms, J. S., 1969. The geochemistry of manganese nodules and associated pelagic deposits from the Pacific and Indian Oceans: Deep-Sea Res. v. 16, p. 335359.

Horn, D. R., Delach, M. N., and Horn, B. M., 1973. Metal content of ferromanganese deposits of the oceans. Tech. Rept. 3, NSFGX33616, Internatl. Decade of Ocean Exploration: Washington (National Science Foundation). 


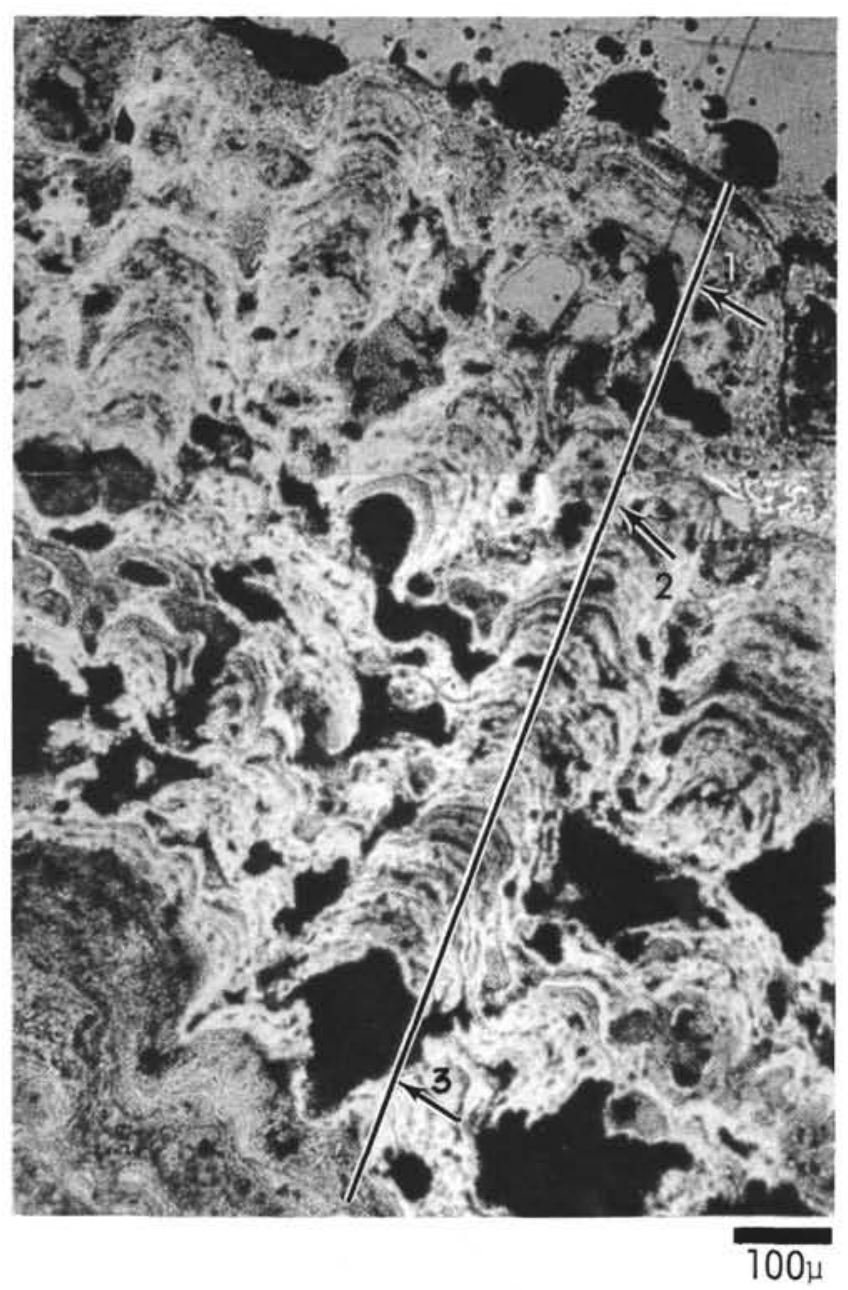

Figure 9. Nodule C, scan 1. Arrows (scan 1) indicate location of spot analyses reported in Table 3.

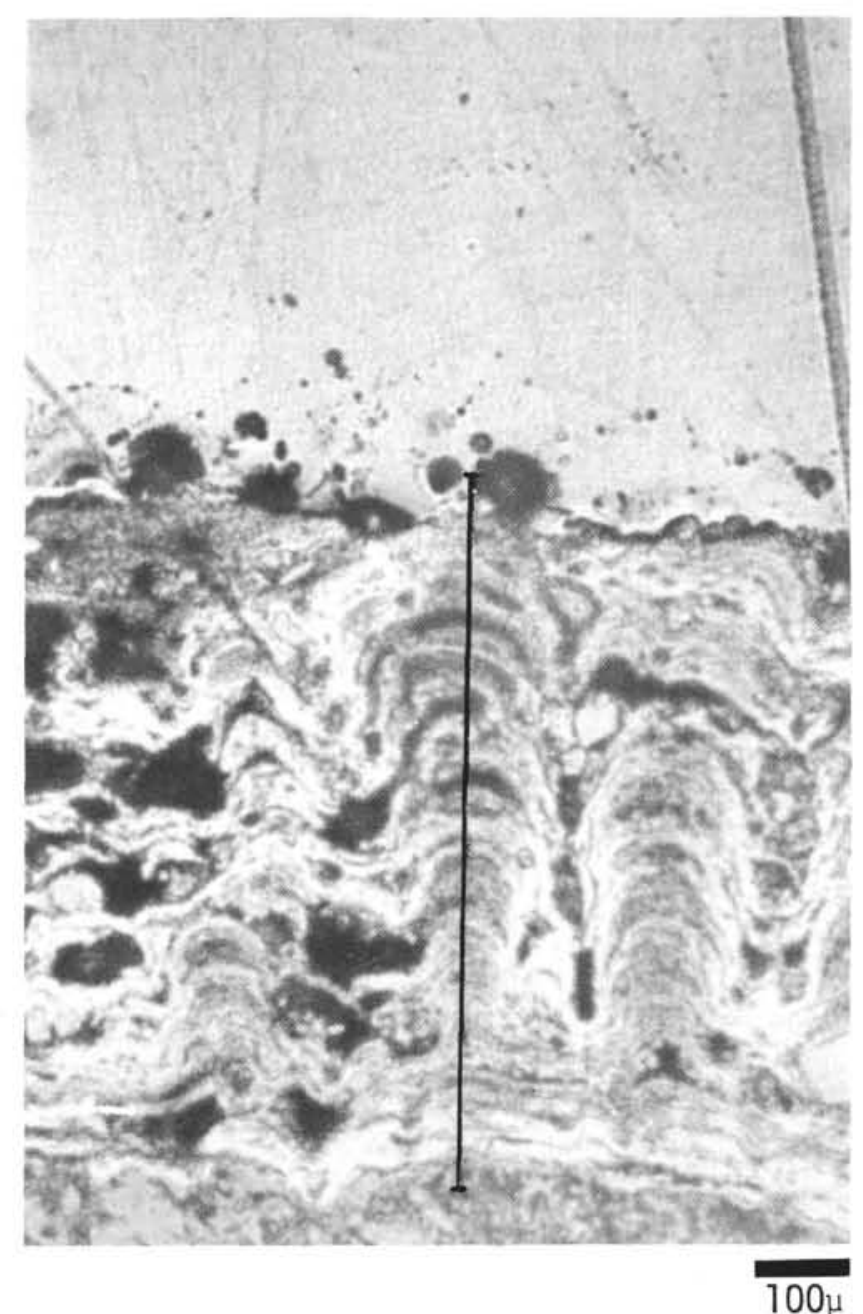

Figure 10. Nodule C, scan 2.

TABLE 3

Percent Element Concentrations for Spot Analyses

\begin{tabular}{|c|c|c|c|c|c|c|c|c|c|c|c|c|c|}
\hline $\begin{array}{l}\text { Nodule, Scan, } \\
\text { and Spot }\end{array}$ & $\mathrm{Fe}$ & $\mathrm{Mn}$ & Co & $\mathrm{Cu}$ & $\mathrm{Ni}$ & $\mathrm{Ti}$ & $\mathrm{Ca}$ & $\mathrm{Al}$ & $\mathrm{Si}$ & $\mathrm{Na}$ & $\mathrm{K}$ & $\mathrm{Zn}$ & Total \\
\hline A - $1-1$ & 16.70 & 11.79 & 0.48 & 0.17 & 0.06 & 1.33 & 1.31 & 1.67 & 14.39 & 0.45 & 0.63 & & 48.91 \\
\hline C - $1-1$ & 20.80 & 15.24 & 0.54 & 0.13 & 0.0 & 1.29 & 0.01 & & 6.13 & & & 0.04 & 44.17 \\
\hline$C-1-2$ & 12.89 & 21.64 & 1.01 & 0.10 & 0.0 & 1.33 & 0.02 & & 3.38 & & & 0.04 & 40.41 \\
\hline
\end{tabular}

Note: Position of spots are given in Figures 5, 8, and 9. 
TABLE 4

Average Percent Concentrations for Nodules from Leg 28, DSDP, Four Pacific Nodules ${ }^{a}$ and Average South Pacific Values ${ }^{b}$

\begin{tabular}{|c|c|c|c|c|c|c|c|c|c|c|c|c|}
\hline $\begin{array}{l}\text { Nodule and } \\
\text { Scan }\end{array}$ & $\mathrm{Fe}$ & Mn & Co & $\mathrm{Cu}$ & $\mathrm{Ni}$ & $\mathrm{Ti}$ & $\mathrm{Ca}$ & $\mathrm{Si}$ & $\mathrm{Al}$ & $\mathrm{Mn} / \mathrm{Fe}$ & $\mathrm{Mn} / \mathrm{Co}$ & $\mathrm{H}_{2} \mathrm{O}$ \\
\hline A - 1 & $\begin{array}{l}5.88 \pm \\
0.37\end{array}$ & $\begin{array}{l}2.29 \pm \\
0.16\end{array}$ & $\begin{array}{l}0.33 \pm \\
0.06\end{array}$ & $\begin{array}{l}0.45 \pm \\
0.10\end{array}$ & $\begin{array}{l}0.21 \pm \\
0.02\end{array}$ & $\begin{array}{l}0.12 \pm \\
0.01\end{array}$ & $\begin{array}{l}1.33 \pm \\
0.07\end{array}$ & $\begin{array}{c}12.38 \pm \\
2.0\end{array}$ & $\begin{array}{l}2.96 \pm \\
2.0\end{array}$ & 0.39 & 6.94 & 14.40 \\
\hline A - 2 & $\begin{array}{l}10.42 \pm \\
1.05\end{array}$ & $\begin{array}{l}7.21 \pm \\
0.84\end{array}$ & $\begin{array}{l}0.34 \pm \\
0.12\end{array}$ & $\begin{array}{l}0.21 \pm \\
0.0\end{array}$ & $\begin{array}{l}0.22 \pm \\
0.0\end{array}$ & $\begin{array}{l}0.14 \pm \\
0.0\end{array}$ & $\begin{array}{l}1.51 \pm \\
0.0\end{array}$ & $\begin{array}{l}9.02 \pm \\
0.0\end{array}$ & $\begin{array}{l}4.60 \pm \\
0.0\end{array}$ & 0.69 & 10.30 & 14.40 \\
\hline A - Average & 8.10 & 4.75 & 0.34 & 0.33 & 0.22 & 0.13 & 1.42 & 10.70 & 2.78 & 0.54 & 8.62 & 14.40 \\
\hline B - 1 & $\begin{array}{c}12.52 \pm \\
0.36\end{array}$ & $\begin{array}{l}7.25 \pm \\
0.25\end{array}$ & $\begin{array}{l}0.46 \pm \\
0.0\end{array}$ & $\begin{array}{l}0.44 \pm \\
0.0\end{array}$ & $\begin{array}{l}0.21 \pm \\
0.0\end{array}$ & $\begin{array}{l}0.23 \pm \\
0.0\end{array}$ & $\begin{array}{l}1.03 \pm \\
0.02\end{array}$ & $\begin{array}{l}0.27 \pm \\
0.05\end{array}$ & $\begin{array}{l}0.40 \pm \\
0.01\end{array}$ & 0.58 & 15.76 & 15.94 \\
\hline B - 2 & $\begin{array}{c}14.49 \pm \\
0.01\end{array}$ & $\begin{array}{l}8.56 \pm \\
0.01\end{array}$ & $\begin{array}{l}0.71 \pm \\
0.08\end{array}$ & $\begin{array}{l}0.13 \pm \\
0.05\end{array}$ & $\begin{array}{l}0.47 \pm \\
0.0\end{array}$ & $\begin{array}{l}0.33 \pm \\
0.01\end{array}$ & $\begin{array}{l}1.54 \pm \\
0.05\end{array}$ & $\begin{array}{c}15.02 \pm \\
0.02\end{array}$ & $\begin{array}{l}0.20 \pm \\
0.0\end{array}$ & 0.54 & 12.05 & 15.94 \\
\hline B - Average & 13.51 & 7.91 & 0.59 & 0.29 & 0.34 & 0.28 & 1.29 & 7.65 & 0.30 & 0.56 & 13.91 & 15.94 \\
\hline C -1 & $\begin{array}{c}15.06 \pm \\
0.54\end{array}$ & $\begin{array}{c}10.39 \pm \\
0.20\end{array}$ & $\begin{array}{l}0.55 \pm \\
0.4\end{array}$ & $\begin{array}{l}0.50 \pm \\
0.4\end{array}$ & $\begin{array}{l}0.22 \pm \\
0.03\end{array}$ & $\begin{array}{l}1.65 \pm \\
0.03\end{array}$ & $\begin{array}{l}1.16 \pm \\
0.03\end{array}$ & $\begin{array}{c}19.63 \pm \\
2.34\end{array}$ & $\begin{array}{l}4.68 \pm \\
0.13\end{array}$ & 0.69 & 18.89 & 12.06 \\
\hline C -2 & $\begin{array}{c}15.24 \pm \\
0.80\end{array}$ & $\begin{array}{l}9.87 \pm \\
0.0\end{array}$ & $\begin{array}{l}0.47 \pm \\
0.0\end{array}$ & $\begin{array}{l}0.42 \pm \\
0.12\end{array}$ & $\begin{array}{l}0.17 \pm \\
0.0\end{array}$ & $\begin{array}{l}0.49 \pm \\
0.01\end{array}$ & $\begin{array}{l}5.85 \pm \\
0.5\end{array}$ & $\begin{array}{l}3.85 \pm \\
0.14\end{array}$ & $\begin{array}{c}10.92 \pm \\
0.69\end{array}$ & 0.64 & 21.00 & 12.06 \\
\hline $\mathrm{C}$ - Average & 15.15 & 10.13 & 0.51 & 0.46 & 0.20 & 1.07 & 3.51 & 11.74 & 7.80 & 0.67 & 19.95 & 12.06 \\
\hline D - 1 & $\begin{array}{l}1.14 \pm \\
0.0\end{array}$ & $\begin{array}{l}0.08 \pm \\
0.04\end{array}$ & $\begin{array}{l}0.24 \pm \\
0.0\end{array}$ & $\begin{array}{l}0.16 \pm \\
0.0\end{array}$ & $\begin{array}{l}0.11 \pm \\
0.0\end{array}$ & $\begin{array}{l}0.51 \pm \\
0.0\end{array}$ & $\begin{array}{l}0.10 \pm \\
0.0\end{array}$ & $\begin{array}{l}26.29 \pm \\
0.0\end{array}$ & $\begin{array}{l}9.25 \pm \\
0.32\end{array}$ & 0.07 & 0.32 & 5.07 \\
\hline $\mathrm{E}-1^{\mathrm{c}}$ & $\begin{array}{l}2.89 \pm \\
0.45\end{array}$ & $\begin{array}{l}0.23 \pm \\
0.02\end{array}$ & $\begin{array}{l}0.02 \pm \\
0.05\end{array}$ & $\begin{array}{l}0.13 \pm \\
0.14\end{array}$ & $\begin{array}{l}0.03 \pm \\
0.08\end{array}$ & $\begin{array}{l}0.05 \pm \\
0.01\end{array}$ & $\begin{array}{l}0.64 \pm \\
0.03\end{array}$ & $\begin{array}{l}22.27 \pm \\
0.0\end{array}$ & $\begin{array}{l}5.75 \pm \\
0.0\end{array}$ & 0.08 & 11.5 & \\
\hline Gal - S74 & 8.19 & 26.2 & 0.19 & 0.60 & 1.25 & & 1.3 & & & 3.2 & 137.89 & \\
\hline V16 - T29 & 11.7 & 18.5 & 0.13 & 0.64 & 1.29 & & 0.6 & & & 1.6 & 142.31 & \\
\hline Msn - $85 \mathrm{G}$ & 19.2 & 10.7 & 0.17 & 0.10 & 0.19 & 0.59 & 1.44 & 12.09 & 2.74 & 0.60 & 62.94 & 17.7 \\
\hline $\mathrm{EH}-16-7$ & 27.9 & 29.5 & 1.00 & 0.05 & 0.52 & & 1.4 & 12.1 & & 1.1 & 29.5 & \\
\hline $\begin{array}{l}\text { Average South } \\
\text { Pacific values }\end{array}$ & 13.92 & 16.61 & 0.595 & 0.185 & 0.43 & 1.007 & & & & 1.19 & 27.92 & \\
\hline
\end{tabular}

${ }^{\mathrm{a}}$ Horn et al., 1973:

${ }^{\mathrm{b}}$ Cronan and Tooms, 1969:

${ }^{\mathrm{c}}$ Also contains $1.48 \pm 0.19 \% \mathrm{~K}$. 


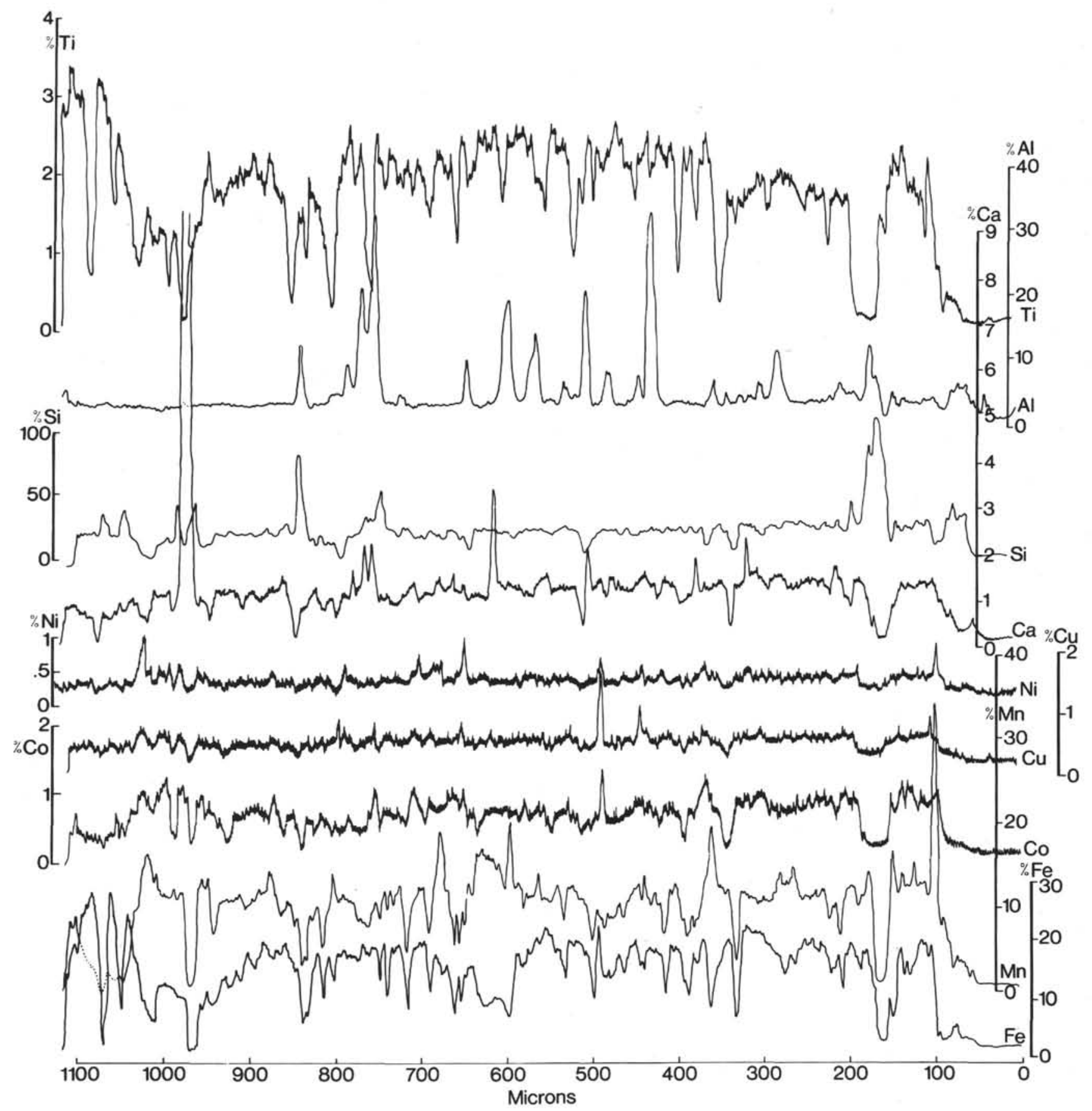

Figure 11. Graph showing percent element concentrations along nodule C, scan 1. 


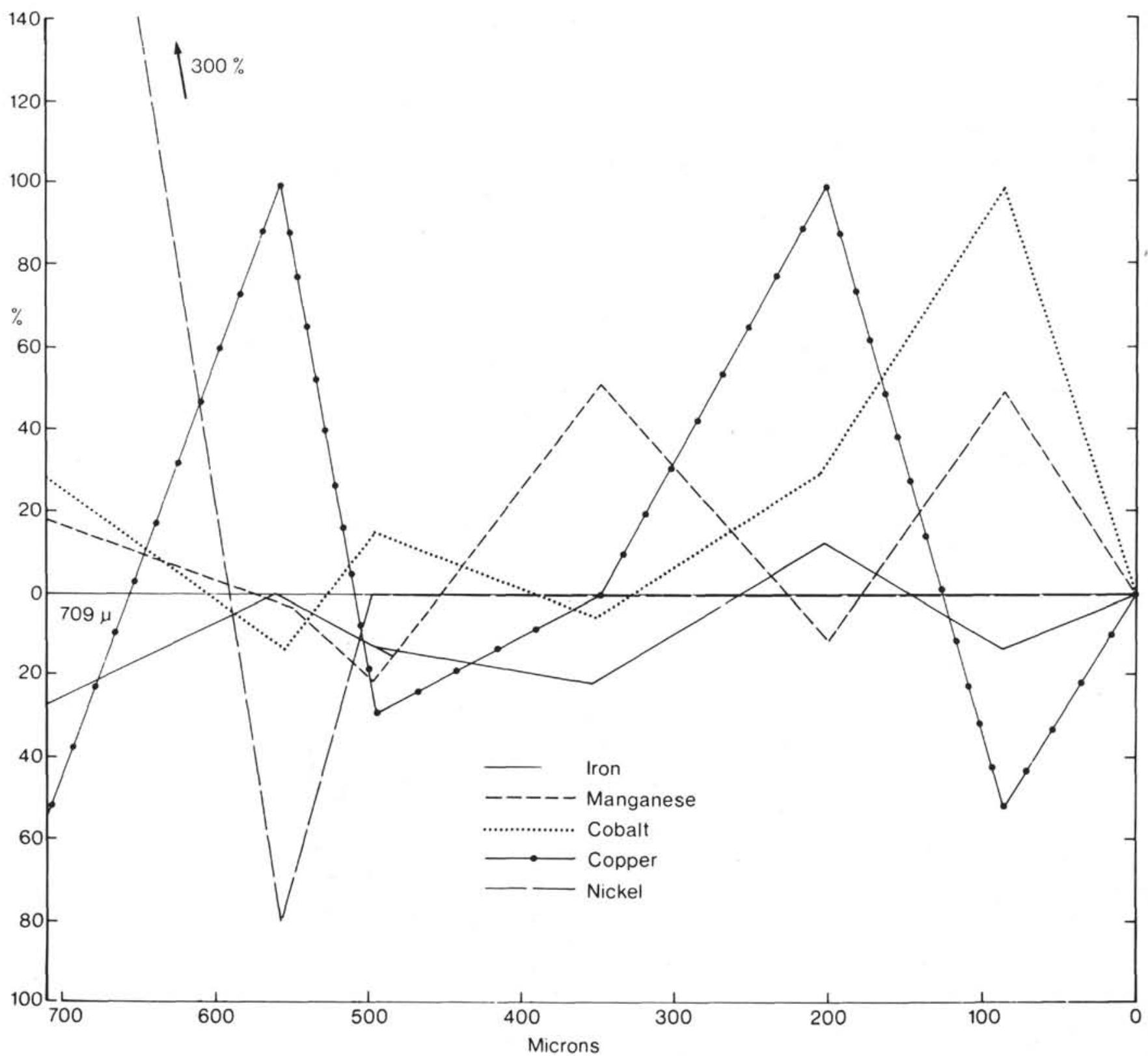

Figure 12. Graph showing relative percent variation for $\mathrm{Fe}, \mathrm{Mn}, \mathrm{Co}, \mathrm{Cu}$, and Ni along the central portion of nodule $\mathrm{C}$, scan 1. 